Jan Paweł II. Posługa myślenia, t. 2, red. ks. B. Kastelik, A. Krupka, ks. R. Woźniak, Kraków 2015, s. 105-116 (Studia nad Myślą Jana Pawła II, 17).

DOI: http://dx.doi.org/10.15633/9788374384933.07

Zofia Zarębianka

\title{
SZTUKA NADZIEI. NADZIEJA W SZTUCE POWOŁANIE ARTYSTY I MISJA SZTUKI W REFLEKSJI KAROLA WOJTYŁY - JANA PAWŁA II
}

Dylematy, które były udziałem Adama Chmielowskiego, głównego bohatera Brata naszego Boga, potencjalnie zarysowują istnienie ostrej dychotomii w myśleniu Karola Wojtyły na temat sztuki. Dokonany przez jałmużnika z Krakowa radykalny wybór, polegający na wyrzeczeniu się wcześniejszej drogi, wskazywać może mianowicie na rzekome przekonanie późniejszego papieża o wyższości czynnej służby bliźniemu nad twórczością artystyczną. Późniejsze o wiele lat wyznanie papieża Polaka, w którym powiedział: „Poezja to wielka Pani, której się trzeba całkowicie poświęcić. Obawiam się, że nie byłem wobec niej zupełnie w porządku" ${ }^{\prime}$, poniekąd wspiera powyższe przekonanie, aczkolwiek naznacza zarazem papieską deklarację wyczuwalną nutą żalu, co z kolei łagodzi ostrość ukazanej antynomii.

Nie wydaje się wszakże, by opisywana $\mathrm{z}$ autorską aprobatą opinia brata Alberta, po wielu latach podzielona przecież w jakiś sposób przez samego pisarza w jego osobistej drodze, rzeczywiście miała oznaczać systemową deprecjację twórczych działan artysty, przeciwstawionych sferze praxis, choć niewątpliwie w swoim paradygmacie aksjologicznym najważniejszą rolę zawsze przypisywał Wojtyła miłości. Sztuka wszakże wcale nie musi się miłości przeciwstawiać. Miłość bowiem przybiera różne formy i postaci, w różny też sposób może być praktykowana, także, jak wolno wnosić z pism przyszłego

$1 \quad$ Słowa kilkakrotnie przy różnych okazjach wypowiadane przez Jana Pawła II. Tak podaje Maciej Zięba w swoim kompendium wiedzy o papieżu, por: M. Zięba, Jestem z Wami. Kompendium twórczości i nauczania Karola Wojtyły - Jana Pawła II, Kraków 2010. 
papieża, poprzez twórczość rozumianą jako funkcja człowieczeństwa ${ }^{2}$. Istotna byłaby przeto intencja, $\mathrm{z}$ jaką podejmowane jest twórcze działanie, i to ona ostatecznie determinowałaby wartość etyczną artystycznego czynu. Sztukę zdaje się Wojtyła traktować w kategoriach interpersonalnych. Jest ona przeto rzeczywistością ustanawiającą przestrzeń kontaktu, stanowi rozmowę o tym, co istotne. Równocześnie jest też dla Wojtyły sztuka, zwłaszcza szuka poetycka, swego rodzaju laboratorium myśli, w którym idee destylują się i przybierają postać czytelną tak dla innych, jak i - niekiedy - także dla samego autora dzieła, dzięki któremu i w samym twórcy dokonuje się głębsze samopoznanie. Dobrze obrazuje ten wątek myślenia o sztuce, przede wszystkim o sztuce słowa, początek poematu Myśl jest przestrzenią dziwną:

Bywa nieraz, że w ciągu rozmowy stajemy w obliczu prawd, dla których brakuje nam słów, brakuje gestu i znaku - bo równocześnie czujemy: żadne słowo, gest ani znak nie uniesie całego obrazu, w który wejść musimy samotni, by się zmagać podobnie jak Jakub ${ }^{3}$.

Dwa elementy w powyższym cytacie zwracają uwagę: wyraźne umieszczenie sztuki w perspektywie antropologicznej, czego wyrazem jest między innymi postrzeganie jej jako zmagania, wysiłku, trudu. Takie widzenie sztuki, aktu twórczego, w wymiarze wysiłku i zmagania, widzenie, w którym odkryć się dają proweniencje romantyczne, szczególnie zaś norwidowskie, takie więc widzenie powróci ponownie w Rekolekcjach dla artystów:

Z jakimż olbrzymim wysiłkiem każdy z nas ściga ślady tego Piękna w tym, co tworzy. Ile czasu pochłaniają ćwiczenia i próby. Ile godzin uderzania w klawisze fortepianu [...]. A to wszystko jest wciąż szukaniem, szukaniem czegoś doskonalszego i pełniejszego $[\ldots]^{4}$.

Akt twórczy jako rzeczywistość procesualna, nieznajdująca nigdy zaspokojenia, ze swojej natury ukierunkowuje zatem człowieka ku Nieskończoności. I po drugie, by powrócić do omawianego cytatu z utworu Myśl jest przestrzenią dziwną, przypisane sztuce antropologiczne nacechowanie wyraża się tu poprzez uznanie jej istotnej roli w przełamywaniu ludzkiej samotno-

$2 \quad$ Por. K. Wojtyła, Ewangelia a sztuka. Rekolekcje dla artystów, Kraków 2011, s. 39.

$3 \quad$ K. Wojtyła, Myśl jest przestrzenią dziwna, [w:] K. Wojtyła, Poezje i dramaty, Kraków 1979, s. 40.

$4 \quad$ Por. K. Wojtyła, Ewangelia a sztuka, dz. cyt., s. 37. 
ści. Obydwa aspekty sytuują sztukę w horyzoncie miłości. Nie ma bowiem miłości bez wysiłku, a praca nad przywracaniem człowiekowi uczestnictwa we wspólnocie jest zawsze działaniem odsłaniającym i oznaczającym troskę, a zatem mającym u źródeł miłość.

W przywołanym na wstępie dramacie chodzi więc raczej nie tyle o podważenie sensu sztuki i zakwestionowanie powołania artysty, ile o wskazanie, iż w indywidualnych postanowieniach rozstrzygającym kryterium powinno być wewnętrzne przekonanie osoby o woli Bożej względem niej oraz poszukiwanie większego dobra, a zatem zawsze działanie podejmowane zgodnie z najgłębszym głosem serca, ukierunkowanego ku prawdzie i dobru. Trudno pomyśleć o innym wytłumaczeniu zarysowanej antynomii między życiem a sztuką, gdy mowa o człowieku, który najpierw jako biskup i kardynał, a potem następca św. Piotra łączył w sobie pasję duszpasterską z pasją tworzenia i wrażliwością artysty, i który zawsze wykazywał głębokie, wynikające z własnego doświadczenia zrozumienie procesu twórczego oraz towarzyszących mu duchowych mielizn i pułapek.

Wygłoszone w 1962 roku Rekolekcje dla artystów oraz napisany w 1999 roku List do artystów są wyjątkowym świadectwem zainteresowania Karola Wojtyły filozofią sztuki i etyką procesu twórczego, przynoszącym refleksję nad powołaniem twórcy i misją sztuki we współczesnym świecie. Szczególną cechą obydwu wystąpień wydaje się umieszczenie rozważań w kontekście nadziei, personalistyczny charakter dyskursu oraz podwójność adresu czytelniczego, wynikająca z dwojakiego pojmowania zarówno samej sztuki, jak i artysty. Poszerzony adres czytelniczy obydwu wystąpień, kierowanych $\mathrm{z}$ jednej strony do każdego człowieka postrzeganego jako twórca własnego życia: „Nie wszyscy są powołani, aby być artystami w ścisłym sensie tego słowa. Jednak według Księgi Rodzaju zadaniem każdego człowieka jest być twórcą własnego życia: człowiek ma uczynić z niego arcydzieło sztuki”, a $z$ drugiej do twórców sensu stricto, pozwala też Wojtyle na płynne przejście z poziomu refleksji uniwersalnej, przeznaczonej dla ogółu, na poziom rozważań bardziej szczegółowych, charakterystycznych tylko i wyłącznie dla ludzi profesjonalnie uprawiających twórczość artystyczną.

Warto też zauważyć, iż ogólne sformułowania odnoszące się do wszystkich zachowują tu swoją ważność i wartość także w odniesieniu do twórców sztuki,

\footnotetext{
Jan Paweł II, List do artystów, [w:] Jan Paweł II do artystów. Artyści do Jana Pawła II, Lublin 2006, s. 32.
} 
na których Wojtyła patrzy przede wszystkim w kontekście ich prerogatyw jako ludzi. Stąd zasadnicza wymowa pytania:

Bóg ostatecznie będzie sądził każdego z nas na podstawie tej zasadniczej wartości wartości mojego człowieczeństwa. I dlatego nie da się na miejsce swojego człowieczeństwa, tej zasadniczej wartości, podstawić żadnej innej. Wobec sądu Boga nie zastąpią człowieka, nawet największego artysty, żadne jego dzieła. Decyduje i rozstrzyga to jedno zasadnicze dzieło, którym jestem ja sam. Co z siebie zrobiłem? I co z sobą zrobiłem?․

Czy moja twórczość, dzieła twórczości, dzieła sztuki - czy to wszystko nie przeszkadza w tworzeniu mojego własnego człowieczeństwa?

Proces twórczy zatem ujmuje Wojtyła przede wszystkim poprzez kategorie etyczne: a więc przez pryzmat odpowiedzialności, służby, dobra wspólnego oraz wartości potraktowanych jako zasadnicze zobowiązania artystów wypływające z ich człowieczeństwa.

Talent jest darem Stwórcy. Darem trudnym. Darem, za który trzeba odpłacić całym swoim życiem. Darem, który rodzi bardzo wielką odpowiedzialność. [...] Bo wszystko, co jest w człowieku wartością, dobrem, talentem, to wszystko rodzi zadanie i odpowiedzialność przed Stwórcą ${ }^{8}$.

Ze wspomnianej podwójności adresu wynika też możliwość włączenia w kontekst rozważań o szeroko rozumianej sztuce słów inaugurujących pontyfikat papieża Polaka.

Pamiętna formuła: „Nie lękajcie się. Otwórzcie na oścież drzwi Chrystusowi!", wypowiedziana przez Karola Wojtyłę w dniu rozpoczęcia pontyfikatu, ustanawia perspektywę ponadziemskiej nadziei, silniejszej od obaw i lęków rządzących ludzkim życiem, nadziei, której spełnieniem i gwarantem jest sam Bóg, czyniący siebie samego rękojmią ostatecznego Sensu. Słowa te dają się interpretować na dwa sposoby. Najpierw jako podstawowe wezwanie, by nie bać się wpuścić Chrystusa do swego życia, by On, Bóg, nie był dla człowieka przyczyną i obiektem lęku, ale by człowiek dostrzegł w Nim nadzieję na rozwiązanie swoich problemów, a raczej by dostrzegł w Nim, w Bogu, rozwiązanie

\footnotetext{
${ }^{6} \quad$ Por. K. Wojtyła, Ewangelia a sztuka..., dz. cyt., s. 42.

7 Por. tamże, s. 40.

8 Por. tamże, s. 36.
} 
wszelkich swych trwóg. Można zauważyć, iż takie rozumienie powyższych słów papieskich znajduje biblijne potwierdzenie w starotestamentowym fragmencie o doskonałej miłości, która znosi lęk. Możliwe do odkrycia kolejne uniwersalne znaczenie rzeczonej formuły kładłoby wyraźniejszy akcent na otwarcie dla Boga drzwi ludzkiego życia, w wyniku czego miałyby zostać przekroczone - ku nadziei - opresywne sytuacje wywołujące w człowieczym sercu trwogę. Przywołane wezwanie papieskie przeznaczone było dla całego świata. Jeśliby je wszakże odczytać jako przeznaczone w pierwszym rzędzie dla artystów, zawierałoby przestrogę przed pewną formą idolatrii, polegającej na subtelnej i często ukrytej, zakamuflowanej tendencji do zastępowania Boga przez rozmaite złote cielce: ubóstwioną i zabsolutyzowaną sztukę lub postawione na piedestale własne ego twórcy.

Żeby nasze własne dzieła nie wyrosły dla nas do rzędu bożyszcz. Żebysmy ich nie ubóstwili. To jest wielka pokusa, zdawać by się mogło: wzniosła pokusa, pokusa artysty: ubóstwić swoje własne dzieła. W nich widzieć namiastkę Boga, bożyszcze. Wtedy się mówi, że sztuka przesłania mi Boga. Ubóstwiając swoje własne dzieła, dzieła swojej wyobraźni, swojego pędzla, swojego dłuta, swojego ciała, swoich warg - ubóstwiając te wszystkie dzieła, jakoś człowiek ubóstwia siebie. To jest wielka tragiczna pokusa ${ }^{9}$.

Gdyby i w drugim ze wskazanych znaczeń formuły inaugurującej pontyfikat szukać sensów adresowanych do ludzi sztuki, to zawierałyby się one w niewypowiedzianym wprost imperatywie, aby nie bać się otworzyć sztuki na treści, tematy, przesłania i wartości religijne, co, zauważmy, w dzisiejszym świecie, poddanym gwałtownym procesom sekularyzacyjnym i presji nośnych ideologii lewackich, nabiera dodatkowej - powiedziałabym: wręcz profetycznej - mocy i nakreśla jednocześnie pewien pozytywny program, projektujący pożądany kształt sztuki, zawsze uwzględniający jej immanentny, choć nie zawsze wyrażony wprost, związek z wymiarem metafizycznym. Następujące słowa z papieskiego Listu do artystów: „artysta nieustannie poszukuje ukrytego sensu rzeczy, z wielkim trudem stara się wyrazić rzeczywistość niewysłowioną"10, poprzedzają i uzasadniają apel Jana Pawła II: „kieruję do was wezwanie, byście na nowo odkryli głęboki wymiar duchowy i religijny sztuki, który w każdej epoce znamionował jej najwznioślejsze dzieła" ${ }^{11}$.

\footnotetext{
9 Tamże, s. 33-34.

10 Por. Jan Paweł II, List do artystów, dz. cyt., s. 52.

11 Tamże, s. 53.
} 
W kontekście powyższych słów z inauguracyjnego przemówienia nauczanie papieża otwiera przed każdym człowiekiem podwójny horyzont nadziei. $\mathrm{Z}$ jednej strony wszystkim wskazuje Boga jako absolutny obiekt wszelkich ludzkich tęsknot, pragnień i oczekiwań, wobec którego tracą swoje bezwzględne znaczenie wszystkie partykularne dążenia i ambicje, ale też wobec którego relatywizują się i nabierają właściwej miary człowiecze lęki, nawet te największe, związane $\mathrm{z}$ utratą życia, bolesnym procesem obumierania, tak $\mathrm{w}$ wymiarze biologicznym, jak i duchowym, czy z narodzinami nowego człowieka. Bóg jawi się tu bowiem jako Ten, który Jest, jest pełnią Bytu, i w Chrystusie każdemu przynosi obietnicę życia wiecznego. $Z$ drugiej strony ów bezwzględny i pewny horyzont eschatologicznej i egzystencjalnej nadziei, nakreślony przez papieża, wymaga od człowieka gestu zawierzenia, swoistego otwarcia się na przychodzącego Boga, bez którego to zawierzenia Bóg pozostawałby w pewnym sensie związany ludzkim lękiem, nieufnością czy wręcz niewiarą, blokującymi ludzką wrażliwość na działanie Jego Ducha. W tym wymiarze nadzieja jawi się więc jako pewien trud, nie jest człowiekowi odgórnie i raz na zawsze dana, potrzebuje ludzkiego wysiłku, świadomej współpracy z łaską na rzecz jej urzeczywistniania się w praktycznych sytuacjach życia każdego $z$ nas. Poniechanie czy może raczej opanowanie lęku oznacza przecież jakiś zasadniczy zwrot wewnętrzny, ukierunkowujący człowieka na Boga niezależnie od zewnętrznych okoliczności, tak by mogły się w nim, w jego sercu i w jego życiu realizować słowa św. Pawła: Cóż nas może odłączyć od miłości Chrystusa? Prześladowanie? Ucisk...? (por. Rz 8, 35). W tym sensie nadzieja wydaje się pewną sprawnością, musi więc być ćwiczona, aby mogła się ugruntować i wzrastać mimo rozlicznych przeciwności, napotykanych raz po raz w życiu, mimo wichrów uderzających w twarz, niejako wbrew naturalnym skłonnościom do pesymistycznej rezygnacji i budowania ciemnych scenariuszy. Nadzieja zatem wymaga wewnętrznej dyscypliny, niezbędnej w zdobywaniu każdej duchowej (i przecież nie tylko duchowej!) sprawności. Postawa nadziei jawi się więc jako swego rodzaju sztuka; człowiek przez całe życie, wciąż na nowo, musi w sobie wypracowywać nadzieję na miarę wyzwań i na miarę lęków, przed którymi staje. Realizacja papieskiego przesłania, by przekraczać próg nadziei, wydaje się ściśle uwarunkowana nie tylko wewnętrzną gotowością do otwarcia na oścież drzwi Chrystusowi, ale też najpierw zgodą na przezwyciężenie swoich lęków i ufne oddanie ich Bogu. W ten sposób odwaga odrzucenia lęku wpisuje się w akt budowania nadziei, staje się jej znakiem i wyrazem. Zarysowana dynamika rozwoju i wzrostu ufności, przeciwstawiona postawie lękliwości i zamknięcia, przedstawia się 
jako prawdziwa sztuka nadziei, wymagająca codziennej pracy nad doskonaleniem własnego człowieczeństwa. To ono, człowieczeństwo, jest w myśli Jana Pawła II najważniejszym obszarem sztuki w najszerszym tego słowa rozumieniu: życia daru Bożego i jako najważniejszego arcydzieła zadanego każdemu człowiekowi. Każdy zatem jawi się w tym ujęciu jako prawdziwy artysta własnego życia, powołany do wydobycia z siebie wszystkich elementów Bożego obrazu, i jako ktoś odpowiedzialny przed Bogiem za kształt nadany własnemu człowieczeństwu.

Szczególnej treści nabiera to wskazanie w odniesieniu do człowieka sztuki, do artysty. Sztuka nadziei rozwija się w nim także poprzez uprawianą przez niego sztukę. Jest bowiem człowiek sztuki, może bardziej jeszcze niż inni, narażony na zniechęcenie, rozgoryczenie i utratę poczucia sensu własnego życia. Grozi mu to zwłaszcza wtedy, gdy wskutek niepowodzeń, niezrozumienia, a czasem także wskutek intryg załamuje się i sprzeniewierza swojemu powołaniu albo poprzez rezygnację $\mathrm{z}$ tworzenia, albo poprzez zdradę wewnętrznej prawdy na rzecz działań o charakterze koniunkturalnym, obliczonych na zdobycie poklasku i odniesienie korzyści. Przed taką postawą, dyktowaną interesownością, przestrzega artystów Jan Paweł II w kierowanym do nich Liście:

Artysta [...] wie także, że musi działać, nie kierując się dążeniem do próżnej chwały ani żądzą taniej popularności, ani tym mniej nadzieją na osobiste korzyści. Istnieje zatem pewna etyka czy wręcz „duchowość” służby artystycznej ${ }^{12}$.

Dla artysty sztuka, a raczej samo uprawianie sztuki, może się przeto stać swego rodzaju szkołą dyscypliny, ćwiczeniem charakteru, w tym także cnoty nadziei, podtrzymywanej w sobie nieraz wbrew racjonalnym przesłankom i wbrew pokusie porzucenia swej drogi, skoro wysiłek podążania nią nie przynosi żadnych spektakularnych efektów, a w miejsce uznania i zrozumienia ze strony otoczenia artysta napotyka pogardę lub po prostu tylko milczenie. Tego rodzaju sytuacja wymaga od człowieka sztuki wielkiego samozaparcia, stanowi bolesną szkołę zapominania o sobie, kształtuje i nadzieję, i pokorę, każe zwracać myśl ku starotestamentowym prorokom, którzy głosili swoje orędzie nawet opornym słuchaczom, w prostym poczuciu, że tak trzeba.

12 Por. Jan Paweł II, List do artystów, dz. cyt., s. 36. 
Omówiona wyżej ogólna i odnosząca się do wszystkich perspektywa uniwersalna nie kwestionuje więc zarysowanej wcześniej perspektywy bardziej partykularnej, w której słowo „sztuka” ma znaczenie węższe i odnosi się do procesu wytwarzania przez twórcę dzieła noszącego znamiona artyzmu. Również i w tym wymiarze uwidacznia się w myśli Wojtyły styk pomiędzy sztuką a nadzieją nie tylko we wskazanym już aspekcie odnoszącym się do osoby artysty, procesu tworzenia i moralnego wymiaru związku pomiędzy nimi. Oczywiście, nie chodzi o strywializowane widzenie owego styku, polegające na prostym umiejscowieniu ludzkich nadziei w sztuce. Takie pojmowanie związku między sztuką a nadzieją byłoby wręcz fałszywe, oparte na tyleż iluzorycznym, ile wyrastającym z pychy, romantycznym $\mathrm{z}$ ducha przekonaniu o zbawczych funkcjach sztuki. Nie o takie więc związki chodzi Karolowi Wojtyle. Nadzieje lokowane w sztuce wywodzi Wojtyła z dwu przesłanek. Po pierwsze więc zauważa, skądinąd oczywiste, możliwości oddziaływania sztuki na sferę ludzkiej wrażliwości, jej poszerzania i kształtowania ku dobru, pięknu i nadziei. Tego rodzaju ujęcie czyni ze sztuki sprzymierzeńca rozwoju człowieka: „obcując z dziełami sztuki, ludzkość wszystkich epok, także współczesna, spodziewa się, że dzięki nim pozna lepiej swoją drogę i przeznaczenie"13, a więc także sojuszniczkę wychowywania go poprzez piękno do nadziei wychylonej poza horyzont doczesności. Sztuka w ujęciu Wojtyły pozostaje też zawsze wyrazem tajemnicy istnienia, jest świadectwem tęsknoty człowieka za nieskończonością i zawsze, choćby pośrednio, stanowi epifanię tajemnicy. Tak rozumiana może być słusznie uznana za swoiste przedpole dla Ewangelii, staje się niejednokrotnie praeparatio evangelica, przygotowując grunt pod Boży zasiew:

Każda autentyczna forma sztuki jest swoistą drogą dostępu do głębszej rzeczywistości człowieka i świata. Tym samym stanowi też bardzo trafne wprowadzenie w perspektywę wiary, w której ludzkie doświadczenie znajduje najpełniejszą interpretację ${ }^{14}$.

Jest też sztuka, co w Liście do artystów podkreśla papież, przypominając stanowisko Marie-Dominique’a Chenu OP, szczególnego rodzaju miejscem teologicznym ${ }^{15}$. We wskazanym ujęciu dobra i wartościowa sztuka służy za-

\footnotetext{
13 Por. Jan Paweł II, List do artystów, dz. cyt., s. 54.

14 Por. Jan Paweł II, List do artystów, dz. cyt., s. 40.

15 Na temat koncepcji loci theologici por. J. Szymik, W poszukiwaniu teologicznej głębi literatury, Katowice 1994.
} 
wsze budowaniu człowieczeństwa, z czym wiązać można (może trochę naiwną, ale niebezpodstawną) nadzieję na odmianę - za sprawą sztuki - człowieka i świata. Wydaje się bezsporne, że w tego rodzaju pojmowaniu misji sztuki daje się odnaleźć ślady romantycznych wzorców, uwidaczniających się szczególnie w przypisywaniu sztuce wzniosłego posłannictwa w zakresie ukazywania tak pojedynczym ludziom, jak i całym społeczeństwom szczytnych ideałów oraz dróg ich realizacji.

Dziedzictwo myślenia zakorzenionego w romantyzmie obecne jest także w pojmowaniu przez Wojtyłę osoby i roli artysty. W szczególny sposób zaznaczają się tu dwa ślady: Norwida oraz Krasińskiego. Norwidowa fraza z Promethidiona: „Bo piękno na to jest, by zachwycało do pracy. Praca, by się zmartwychwstało"16 determinuje teorię Wojtyły na temat misji artysty jako tego, którego wysiłek ma ukazywać ludziom najwyższe cele ich eschatologicznego przeznaczenia. Mam wrażenie, iż wskazany wątek, choć istotny w całokształcie przekazu Karola Wojtyły - papieża Jana Pawła II przeznaczonego dla ludzi sztuki, jest zarazem najmniej oryginalny i, by tak rzec, najbardziej oczywisty.

Wkład własny papieża, a wcześniej już biskupa Wojtyły, zaznacza się $\mathrm{w}$ rozważaniach o etycznym nacechowaniu powołania artysty. Tu z kolei istotny wydaje się wpływ refleksji zapisanej przez Krasińskiego w Nie-boskiej komedii, ze słynnym, wielokrotnie przytaczanym zdaniem wypowiedzianym przez hrabiego Henryka: „Przez ciebie płynie strumień Piękności, ale ty nie jesteś pięknością", dającej asumpt do rozważań Wojtyły o potrzebie ideowej i moralnej jedności między artystą a jego wytworami: „Chodzi o to, ażeby człowiek był harmonijny od wewnątrz. Oczywiście, że wielką wartością jest sumienie artystyczne, ale musi się ono związać z tą właściwością najgłębszą, jaką stanowi sumienie moralne"17.

Oryginalność poglądów Karola Wojtyły na problematykę aktu twórczego wyraża też dialogiczne ujęcie sztuki: „poprzez swoje dzieła artysta rozmawia i porozumiewa się z innymi"18. W koncepcji przyszłego papieża dzieło sztuki jest bowiem formą rozmowy twórcy $\mathrm{z}$ odbiorcą, co zarazem sytuuje każdy akt twórczy w perspektywie personalistycznej. Nie chodzi więc tylko o to, że każdy akt twórczy jest aktem człowieka, ale i o jego finalne ukierunkowanie

16 C. K. Norwid, Promethidion. [w:] tenże, Pisma wybrane, t. 2, oprac. W. Gomulicki, Warszawa 1968, s. 216.

17 K. Wojtyła, Ewangelia a sztuka..., dz. cyt., s. 50.

18 Jan Paweł II, List do artystów, dz. cyt., s. 33. 
ku drugiemu. Oznacza to zatem także, iż dzieło wyrasta z duchowej hojności, jest sposobem dzielenia się twórcy swoim bogactwem wewnętrznym i stanowi wyraz tego bogactwa. Nakłada to na artystę szczególnego rodzaju odpowiedzialność. Jej odzwierciedleniem byłaby biblijna zasada „z obfitości serca mówią usta", zobowiązująca każdego człowieka, w tym wypadku w szczególny sposób artystę, do traktowanej jako powinność dbałości o to, czym się karmi, czym napełnia swoje wnętrze, w jaki sposób pracuje nad pomnożeniem ofiarowanego - i zadanego - mu przez Boga daru, a w konsekwencji, czym promieniuje na innych. Im większy dar, tym większa odpowiedzialność. Ewangeliczna przypowieść o talentach, przywołana przez biskupa Wojtyłę w rekolekcyjnych rozważaniach, znajduje tu specyficzną wykładnię. W świetle tych nauk jednym $z$ największych grzechów artysty byłby zastój, powielanie wcześniejszych rozwiązań, poniechanie poszukiwań coraz doskonalszych form wyrazu dla wewnętrznej prawdy oraz brak rozwoju.

Bardzo niezgodne z naszym powołaniem jest lenistwo, brak pewnego wysiłku, ażeby wydobyć z siebie jakieś wartości, wartości twórcze. Lenistwo i twórczość to są dwie postawy, które się sobie wzajemnie sprzeciwiają ${ }^{19}$.

Ta postać duchowego lenistwa stanowi według rekolekcjonisty realne zagrożenie tak dla osoby artysty w wymiarze jego osobowej i osobistej odpowiedzialności za powierzony mu twórczy talent, jak i ostatecznie dla sztuki, dla jakości artystycznej wytworów. Gdy będą one ekspresją skarlałego ducha, same nieuchronnie też będą karłowate i jałowe.

Uwidacznia się w tym punkcie istotna odmienność myślenia Karola Wojtyły o sztuce w porównaniu z klasyczną aksjologią tomistyczną. Przypomnę: św. Tomasz jednoznacznie odróżniał wartość artystyczną dzieła od wartości moralnej twórcy. Ta zasada uniezależnienia oceny tworu artystycznego od oceny wartości życia realnego autora obowiązuje po dziś dzień w aksjologii twórczości i pozostaje ważnym, obiektywnym kryterium chroniącym przed nieuprawnionymi zakusami utożsamiającymi obydwa obszary i w efekcie często prowadzącymi do nadużyć i nieporozumień.

Personalistyczne stanowisko Karola Wojtyły tę tomistyczną zasadę nie tyle może podważa w sposób skrajny, ile ją modyfikuje i uzupełnia. Wojtyła mianowicie postrzega twórcę oraz jego dzieło w kategoriach antropologicznych, w konsekwencji ujmując związek między dziełem i twórcą w sposób

19 K. Wojtyła, Ewangelia a sztuka..., dz. cyt., s. 54, 55. 
zdecydowanie bardziej integralny. Uznaje przeto, iż dzieło stanowi, przynajmniej do pewnego stopnia, ekspresję duszy artysty, w związku z czym nie powinien istnieć żaden rozdźwięk pomiędzy ideami głoszonymi w sztuce a życiem twórcy, w którym owe idee, wpisane w dzieło, mają się manifestować. Nie oznacza to, jak sądzę, definitywnego zakwestionowania przez Wojtyłę sformułowanej przez Akwinatę reguły rozdziału w samej ocenie wartości dzieła sztuki, zwraca wszakże uwagę, iż dzieło zawsze pozostaje wytworem myśli i pracy konkretnego człowieka i w tym sensie nie jest czymś niezależnym, niepowiązanym ze światem doznań, przekonań i doświadczeń, które tego twórcę jako człowieka ukształtowały i w przetworzonej formie znajdują mniej lub bardziej pośredni wyraz w dziele.

Tworząc dzieło, artysta bowiem wyraża samego siebie do tego stopnia, że jego twórczość stanowi szczególne odzwierciedlenie jego istoty - tego, kim jest i jaki jest. [...] Artysta bowiem, kiedy tworzy, nie tylko powołuje do życia dzieło, ale też poprzez to dzieło jakoś objawia swoją osobowość ${ }^{20}$.

Przez położenie akcentu na integralność twórcy i dzieła intensyfikuje się w refleksji Wojtyły przeświadczenie, szczególnie mocno podkreślane, o moralnym wydźwięku procesu twórczego oraz o etycznej misji sztuki w świecie współczesnym.

W przekonaniu Wojtyły, by rzecz ująć najprościej, sztuka ma służyć dobru człowieka i pomagać mu w zbliżeniu się do Boga i w kontemplacji Jego piękna. Kluczowe pozostaje tu słowo służba. Rozumienie powołania artysty oraz samej sztuki jako służby człowiekowi ujawnia prymat miłości jako konstytutywnego celu człowieka.

Wyrazem dobra pozostaje zaś piękno w myśl przypomnianej i podzielanej przez papieża scholastycznej zasady „Ens et bonum/pulchrum conventuntur". To w tej, między innymi, zasadzie daje się odszukać uzasadnienie dla integralnej wizji Wojtyły, podkreślającego z jednej strony imperatyw etycznej jedności między twórcą a dziełem artystycznym, z drugiej imperatyw harmonii między wymiarem etycznym i estetycznym w obrębie samego dzieła. W tym ujęciu dzieło, które nie służy dobru człowieka, nie ma też w sobie piękna, gdyż te dwie wartości pozostają w personalistycznie ukierunkowanej koncepcji Karola Wojtyły nierozdzielne i nierozłączne, co prymarnie wynika z faktu, iż to Bóg jest jedynym dobrem i pięknem.

\footnotetext{
20 Por. Jan Paweł II, List do artystów, dz. cyt.
} 
Ostatecznie więc sztuka jest w koncepcji Jana Pawła II drogą do Boga: „Niech różnorakie drogi, którymi podążacie, artyści całego świata, prowadzą was wszystkich do owego bezmiernego Oceanu piękna, gdzie zachwyt staje się podziwem, upojeniem i niewymowną radością"21, skoro zaś jest drogą do Boga, jest także drogą nadziei.

$21 \quad$ Jan Paweł II, List do artystów, dz. cyt., s. 56. 